\title{
Factors Affecting the Application of Communicative Language Teaching CLT in Syrian Schools
}

\author{
Moustafa Armnzai' ${ }^{1}$ Hussien Alakrash ${ }^{2}$ \\ ${ }^{1}$ Department of English and Foreign Languages, Tezpur University, Assam, India. \\ ${ }^{2}$ School of Language Studies and Linguistics, Faculty of Social Sciences and Humanities, Universiti \\ Kebangsaan Malaysia, Bangi, Malaysia. \\ Corresponding author: Hussien Alakrash [hussienalakrash94@gmail.com]
}

\begin{tabular}{llll}
\hline Received: $05 / 02 / 2021$ & • & Accepted: 23/03/2021 & Published: 31/03/2021
\end{tabular}

\begin{abstract}
The main purpose of CLT is to help EFL learners to communicate with other English language speakers. Practicing speaking and communication is limited in Syrian educational institutions. Hence, to improve the communicative skills of learners, the CLT approach of the teachinglearning process is highly recommended. The study aims to identify the challenges that negatively affect the valid application of CLT in Syrian public schools in Aleppo governance. The study employed a fully quantitative research design. A survey questionnaire was used as a data collection instrument. A number of 50 English language teachers from 25 schools were randomly selected. The collected data were analysed descriptively using SPSS (25) software. Teachers despite their awareness of the importance of CLT, faced many challenges. The results showed four types of challenges namely; teachers-related challenges: lack of training, lack of authentic materials, lack of English cultural knowledge. Students related challenges: low proficiency, passive learning style, lack of motivation. Education system-related challenges: lack of support, too large classes, unsuitable curriculum. Finally, CLT related challenges: lack of effective and efficient assessment instrument, lack of teaching materials. The study provided a comprehensive approach towards better implementation of CLT in the EFL context. Implications and recommendations were discussed in light of the findings.
\end{abstract}

Keywords: Communicative Language Teaching; CLT; Challenges; EFL, English teaching and learning; Syria.

\section{Introduction}

A preference for more productive ways of teaching foreign or second languages has characterized the history of language teaching. For more than a century, issues such as grammar rules in language curriculum, activating accuracy along with fluency in language teaching, developing the skills of producing and receiving a language, and learners' motivation have been the core of debates and discussions within teaching professions (Alamri, 2018). The communicative language teaching (CLT) method emerged first in England in 1970. This approach was considered innovative because the focus was on using language as a tool of communication within the classroom environment (Ozsevik, 2010). Western countries accepted this technique for the fact that it is mainly an ESL (English as a second language) method. From English-speaking countries, it reached all the world's countries. Therefore, and because of its revolutionary characteristic, (CLT) was the most influential method in the language teaching field, not only in ESL but also in EFL (English as a foreign language) Settings (Chang, 2011; Alakrash \& Razak, 2020a). 
Despite its influencing traits, there was no consensus acceptance of CLT and the possibility of applying it to EFL contexts (Mustapha \& Yahaya, 2013). Some ELT (English language teaching) scholars have stressed the importance of traditional methods and the beneficiary role they play in EFL environments (Roy, 2016; Alakrash et al., 2020; Alkamel \& Chouthaiwale, 2020). However, other scholars have extremely taken an adoptive position for CLT in Asian schools and universities. None of these two extremes was preferred by the majority of ELT scholars, who defended the fact that the full implementation of CLT in Asian countries is almost impossible (Ansarey, 2012). Therefore, they advised going beyond the obstacles that hinder a wise and effective implementation of CLT in Arab environments (Al Asmari, 2015).

The theory of language as communication has a huge impact on the communicative language teaching technique. The main purpose is for learners to use the target language in various contexts and to fulfill the function of the language they are learning (Sreehari, 2012; Razak, Yassin, \& Maasum, 2020). CLT mainly aims to develop the communicative skills of foreign language learners, besides, to enrich their competence with the knowledge needed and activating their performance to be able to use their target language effectively for communication. It is more accurate to think about CLT as an approach rather than a method because it influences the practical part of language teaching (Farooq, 2015).

Communicative competence is considered the main target of CLT. This competence includes "what to say and how to say it appropriately based on the situation, the participants, and their roles and intentions" (Ozsevik 2010). The teacher's role inside the classroom is highly significant. They should be a "model for correct speech and writing" and help "produce plenty of error-free sentences" (Richards 2006). In other words, the teacher should improve the classroom environment to be more suitable for group working and increasing student-oriented role inside the class rather than "relying on the teacher for a model" (ibid). In this situation, a teacher turns to be a facilitator, co-learner, and guide. Learners will get the chance to self-learning and improvement and the teacher will supervise and facilitate the process of learning (Wei, Lin, \& Litton, 2018).

English language teaching in Syria is facing many difficulties, mainly because of the effect of the mother tongue on the education process. In public schools, Arabic is used for instructions and teacherstudent communication frequently during classes (Khoja \& Mohapatra, 2017). In the higher institutes of languages, the situation is different; English is the mean of communication inside the class for all levels except zero where Arabic is used to give instructions and translate some difficult lexical items. One of the curricula used the New Headway advanced series, which is preferred for its authenticity, attractiveness, functionality, practicality, and well-organizing. The syllabus facilitates communication, connection, and comparisons. These features provide a suitable CLT environment with discoursal and sociocultural features of language (Zare-Behtash \& Banaruee, 2017; Alakrash et al., 2020). However, teachers still suffer from implementing CLT because of challenges in terms of teachers, students, the education system, and CLT itself.

This study aims to investigate the challenges that affect applying CLT in public schools in Syria and to shed the light on some solutions for these challenges. Education System in Syria:

Research Question

1. What difficulties and challenges do the teachers face in adopting CLT?

2. What are the challenges caused by students in implementing CLT in the classroom?

3. What are the challenges related to the education system in Syria in implementing CLT?

4. What are the challenges related to CLT in implementing CLT in teaching? 


\section{Communicative Language Teaching (CLT)}

CLT, according to Harmer (2003), "has different multitude meanings to different people". (NGOC \& Iwashita, 2012) stands against the idea of CLT's validity as a method due to its failure to account for the context of language teaching in many centuries. Therefore, he calls for the implementation of the Context Approach. However, Butler (2011) defended the approach as they indicate, "A communicative methodology will ... exploit the classroom as a resource with its own communicative potential". Butler (2011) and Alakrash and Razak (2019) advises the teachers to adapt rather than adopt CLT. Teachers. For Dornyei (2013), the teacher is responsible for separating their beliefs from "what seems right in the local context", which would be useful for both the teacher and the learners. Going back to the history of English language teaching, Van Nguyen (2010) notices that in the early twentieth century, this field was independent due to the need of teaching English in colonies. After that, and because of the global development in the fields of business, communication and trade, English became the lingua franca of the entire world. Therefore, English as a second language (ESL) and English as a foreign language (EFL) appeared to concentrate on English skills such as writing, reading, listening, and speaking in the 1950s (Khoja \& Mohapatra, 2017).

In the 1970s, the approach of CLT was introduced to the field of English Language Teaching ELT. The core and priority of using this approach are to activate communication. Developing a student's communicative competence, which is the students' ability to comprehend the input of language and apply it, as an output in a social context, is the basic aim of CLT. This competence can be triggered by providing students with real-life exercises that can invoke their communicative competence to participate in producing the target language effectively (Rahman, Pandian, \& Kaur, 2018). Jafari Shokrpour and Guetterman (2015) have agreed that CLT is the most prevailing approach since its establishment. Fadilah (2018) put some conditions for implementing CLT, they focused on the importance of authentic materials for CLT, which enable students to interact and communicate in a real-life environment. Highly qualified teachers, who can effectively use a wide range of materials, should be employed to maintain the creativity of the classroom. Sauvignon (2002) divided communicative competence into three parts (i) Linguistic competence, which is the unconscious knowledge of grammar, vocabulary, and syntax. (ii) Sociolinguistic competence, which is the ability of a person to be part of a conversation in a coherent and precise way. (iii) Discourse competence, which is effective communication without any breakouts or problems (Mowlaie \& Rahimi, 2010).

Another goal for CLT is to improve the accuracy and fluency of the students. Fluency is defined by Whong (2013) and Alakrash and Razak (2020b) as "the natural language use occurring when a speaker engages in a meaningful interaction and maintains the comprehensible and ongoing communication despite limitations in his or her communicative competence". He mentioned some features of fluency such as meaningful use of language, along with communication strategies and not predicting what to say, in addition, to contextualize the language spoken by both sides of the conversation.

Seven points that CLT implements are mentioned by Ahmed (2016): preparing students to communicate in real life by providing them with the needed communicative skills, focusing on the learner-oriented collaborative activities, going beyond the classroom in developing students communicative skills, the fluency is more important than the accuracy, effective relationship between function and form, mixing the organizational with the pragmatic aspects of language, and focusing on the communicative competence of learners. 


\section{Syrian Education System}

Before the year of Syrian independence in the year 1946, The education system, primarily in schools in Syria, has been used by the American and French forces as a medium to employ influences over the social and religious life of Syrian people. Nevertheless, American and French schools delivered proper education, including the study of languages to students, but this education system is only accessible to the higher society and elites. In other words, the ability to be able to speak in English and French is notable. Transforming the private education system into state schools was eventually impacting the foreign language skills among the students. Though still many of the private institutions did their best to preserve their system and status, in which even though they were converted to state schools, the upper-class elite Christians in larger cities managed to keep and practiced their foreign language and delivered the language used among younger generations.

After the reformation of education in the year 2002, the government has taken a step by making sure the English language is taught in school, starting from students in their 1st grade. Non-native teachers were assigned to teach the language to students for seven hours a week as the primary language subject. The French language has also been taught as a foreign language among school students from the 7th until 12th grade. The enaction of the education reform policy has presented the step taken by the Syrian government to highlight the importance of the English language to be presented as a priority in the language policy. This is highly due to the status of the English language served as a lingua franca, and hence the Syrian government wanted to keep along and stay connected with the rest of the world. Although the English language seems to be call attention to, French is still kept as a language subject in schools, and its effect on the Syrian education system was not dissipated.

\section{Relevant Studies}

Communicative language teaching's challenges have been striking the interest of the researchers of this field especially in the countries where English has been taught as a foreign language like Syria, Turkey, or Saudi Arabia. Al Asmari (2015) investigates the challenges facing implementing CLT in the university EFL context in Saudi Arabia, specifically at Taif University, English language center. The study resulted in many factors affecting the process of applying CLT in Taif University, such as the poor English proficiency of the students, the difficult accessibility of CLT resources, lack of CLT training and motivation, etc. Mehtab (2012) conducted a similar study to (Nayeen, Islam, Chowdhury, $\&$ Zayed, 2020) but on the school level in Bangladesh to find out those school teachers also suffer from implementing CLT in their classes, and the difficulties were due to the education system in Bangladesh, the students and the method itself. Prastyo (2015) used a questionnaire and interview methods, on 50 teachers teaching English, in one of the Iranian high schools to discover what hinders CLT from being applied to the classroom there. Coskun (2011) related teachers' problems in implementing the CLT approach in Taiwan to the examination which is a grammar-based one. Khoja and Mohapatra (2017) visited eight High schools in Syria in addition to the Department of English in Tishreen, Syria to conclude that the communicative features were ignored and Arabic were the mean of communication and instruction. Moreover, the students' main goal is to pass the tests. Therefore, the teacher there was suffering to apply the CLT approach (Razak et al., 2018).

\section{Research Methodology}

This study aimed to investigate the challenges that hinder applying the Communicative Language Teaching (CLT) approach in Syrian public schools. A quantitative research design was used to analyse the data. Reading previous studies has led the author to choose a descriptive statistical design because they worked in the same field of study and adapted the same design. Using this design enabled the author to perfectly Collect data and statistically analyze them (Crosswell \& Poth (2016). Descriptive 
studies are "useful for investigating a variety of educational problems and concerned with assessing attitudes, readiness, opinions, preferences, demographics, practices and procedures" Gay \& Mills (2019). Ten Syrian public schools, located in Aleppo, constructed the sampling frame for this study. A proportional random sampling technique was used to generate the samples. Teachers from the aforementioned schools constituted the sample of the study. The total population of the teachers was 50 (20 males and 30 females) aged 25 to 40, with teaching experience ranging from four to 20 years. According to Krejcie and Morgan (1970) in their sampling table to determine the sample size from a given population, for a population of 50, sampling of 44 is required.

A questionnaire was adapted to collect data. First demographic information was required such as gender, age, teaching experience, and the level of education. The second part of the questionnaire contained four sections (Teacher related, Student related, educational-related, and CLT-related challenges). To check these lecturers' personal experience with the CLT approach, a written questionnaire was created which contains yes-no questions. Each participant was required to give a fixed response by choosing "yes" or "no". a pilot study was conducted where the reliability of the instrument of the collected data was tested using Cronbach's Alpha test. Two professors at a higher institute of languages validated the questionnaire. The questionnaire used the four-point ordinal scale with endpoints of (major challenge, challenge, mild challenge, and not a challenge) for the respondent to select the level of challenge on the provided items. This scale was used to enable participants to sort out items in a way close to the structural pattern of the scale, resulting in higher reliability and validity (Chang, 1994).

\section{Findings and Discussion}

The questionnaire was designed to have two parts, the first part contains demographic information about the participants. The second part consists of four sections related to the challenges of implementing the CLT approach in terms of teachers, students, the education system, and the approach itself. The authors adopted a questionnaire by Al Asmari (2015).

\subsection{Demographic Information}

This is the first part of the questionnaire which is important to know the aspect that may affect the teacher's ability to apply CLT in Syrian classrooms. The finding of demographic information and questionnaire are shown. The percentage and frequency of age, gender, language teaching experience, and teachers' levels of education are presented. Data resulted that $54 \%(\mathrm{n}=27)$ teachers are females, while $46 \%(n=23)$ are males. Regarding ages, the findings showed variation in ages, hence, two age groups were created. 20 to 30 years old and 31 to 50 years old. Teachers belonging to the former age group were $56 \%(n=28)$, the teachers belonging to the latter age group are $44 \%(n=22)$ of the total number of teachers as shown in Table 1.

Table 1. Findings of respondents' age and gender

\begin{tabular}{lll}
\hline Demographics & N & \% \\
\hline Male & 23 & 46 \\
Female & 27 & 54 \\
20-30 years old & 28 & 56 \\
31 - 50 years old & 22 & 44 \\
\hline
\end{tabular}

Other demographic findings are of the respondents' language teaching experience and their level of education. The results found that $40 \%(\mathrm{n}=20)$ of the participants have $1-5$ years of English language teaching experience, $24 \%(n=12)$ of the participants have $6-10$ years of experience. $36 \%(n=18)$ have 
$11-20$ years. The results of the level of education demographic part of the questionnaire showed $88 \%$ $(n=44)$ had or are pursuing an M.A degree, while $12 \%(n=6)$ had or pursuing a Ph.D. degree (see Table 2).

Table 2. Findings of respondents' teaching experience and level of education

\begin{tabular}{lll}
\hline Demographic & N & \% \\
\hline $1-5$ years of experience & 20 & 40 \\
$6-10$ years of experience & 12 & 24 \\
$11-20$ years of experience & 18 & 36 \\
B.A. & 44 & 88 \\
M.A & 6 & 12 \\
\hline
\end{tabular}

\subsection{Challenges}

This part consists of four sections; teacher-related challenges, student-related challenges, education system-related challenges, and CLT-related challenges. The questionnaire was used to revile the difficulties that are facing teachers to implement CLT in Syrian classrooms.

\section{A. Teacher-related Challenges}

The part of the questionnaire shows the teachers' perspectives in terms of the difficulties they experience in their classroom using CLT as shown in Table 3.

Table 3. Teacher-Related Difficulties and Challenges

\begin{tabular}{|c|c|c|c|c|c|c|c|c|c|}
\hline & \multirow[t]{2}{*}{ Statements } & \multicolumn{2}{|c|}{$\begin{array}{l}\text { Major } \\
\text { challenge }\end{array}$} & \multicolumn{2}{|c|}{ Challenge } & \multicolumn{2}{|c|}{$\begin{array}{c}\text { Mild } \\
\text { challenge }\end{array}$} & \multicolumn{2}{|c|}{$\begin{array}{l}\text { Not a } \\
\text { challenge }\end{array}$} \\
\hline & & $\mathbf{N}$ & $\%$ & $\mathbf{N}$ & $\%$ & $\mathbf{N}$ & $\%$ & $\mathbf{N}$ & $\%$ \\
\hline 1 & $\begin{array}{l}\text { Teachers have misconceptions about } \\
\text { CLT. }\end{array}$ & 6 & $12 \%$ & 13 & $26 \%$ & 20 & $40 \%$ & 11 & $22 \%$ \\
\hline 2 & $\begin{array}{l}\text { Teachers lack knowledge about } \\
\text { English culture. }\end{array}$ & 3 & $6 \%$ & 4 & $8 \%$ & 4 & $8 \%$ & 39 & $78 \%$ \\
\hline 3 & $\begin{array}{l}\text { Teachers have little time to develop } \\
\text { materials for communicative activities. }\end{array}$ & 3 & $6 \%$ & 26 & $52 \%$ & 14 & $28 \%$ & 7 & $14 \%$ \\
\hline 4 & $\begin{array}{l}\text { Teachers have fewer resources for } \\
\text { communicative material development. }\end{array}$ & 15 & $30 \%$ & 21 & $42 \%$ & 12 & $24 \%$ & 2 & $4 \%$ \\
\hline 5 & $\begin{array}{l}\text { Teachers lack training about the CLT } \\
\text { approach. }\end{array}$ & 9 & $18 \%$ & 23 & $6 \%$ & 15 & $30 \%$ & 3 & $6 \%$ \\
\hline 6 & $\begin{array}{l}\text { There are few opportunities for } \\
\text { teachers to get CLT training. }\end{array}$ & 25 & $50 \%$ & 15 & $0 \%$ & 8 & $16 \%$ & 2 & $4 \%$ \\
\hline 7 & $\begin{array}{l}\text { Teachers lack access to authentic } \\
\text { materials such as newspapers, } \\
\text { magazines, movies, etc. }\end{array}$ & 23 & $46 \%$ & 11 & $22 \%$ & 10 & $20 \%$ & 6 & $12 \%$ \\
\hline
\end{tabular}

The findings indicate that the majority of the teachers $40 \%(n=20)$ think that having misconceptions about CLT is a mild challenge while only $12 \%(n=6)$ of them think that it is a major challenge. According to Kalanzadeh et al. (2013), a common misconception for teachers is that CLT only targets fluency and ignores accuracy for not focusing on the form. However, for (Freeman; 2003:132) the goal 
of CLT is not only fluency, but rather accuracy also is targeted. Some teachers may think that CLT represents an obstacle in preparing the student for important exams according to teachers.

Most of the teachers, $78 \%(\mathrm{n}=39)$ agreed that lacking sufficient knowledge of English culture is not a challenge, because most of them studied English literature and read many novels, dramas, and poetry that reflect old and modern English cultural aspects. The time required to develop materials for CLT activities represents a challenge but not a major one for more than half the teachers $52 \%(n=26)$, which might be caused by the teacher being pressurized by having to teach in more than one institute to make ends meet. The limitation in resources for communicative materials development has apparently affected teachers negatively to apply CLT in their classrooms, only $4 \%(n=2)$ think that it is not a challenge. Most of the teachers $46 \%(n=23)$ think that the lack of training about the CLT approach is a challenge. Khan (2011) indicates that some teachers have a misunderstanding regarding their training to improve skills needed in the field of teaching, the notion of academic embarrassment to join a training course is common. However, the fact is that training is highly required to refine teachers' skills and abilities, especially in the time of advancement and cutting-edge technological devices and global communication which make it easy for the teacher to access various training programs. 50\% of teachers also agreed that the opportunities for getting proper CLT training are limited in Syria.

Respondents also reported that the accessibility to authentic resources for communicative materials is a major challenge for $46 \%(\mathrm{n}=23)$ of the total number of teachers. One way to solve this problem is that teachers to design their own materials using the internet, this is doable but o difficult and timeconsuming, it adds more burden on the shoulders of teachers and they may not have equipped classes to handle applying CLT materials they created. Uncommunicative study materials can prevent adopting CLT, however, teachers these days can approach some resources or books which can help them achieve their CLT goals easily. Bridging the gap between students in the classroom and the CLT activities is teachers' main task, therefore teachers should have the proper language proficiency to communicate and positively reflect the CLT tasks on their students.

\section{B. Student-related Challenges}

The second section of the second part of the questionnaire illustrates student-related challenges and difficulties. The challenges related to students that are mentioned in the questionnaire were low English proficiency level, passive learners, less confidence, CLT resistance, and lack of motivation. Table 4 below shows the teachers' opinions regarding these challenges as shown in Table 4 .

Table 4. Student-Related Difficulties and Challenges

\begin{tabular}{|c|c|c|c|c|c|c|c|c|}
\hline \multirow[t]{2}{*}{ No. } & \multirow[t]{2}{*}{ Statements } & \multicolumn{2}{|c|}{$\begin{array}{c}\text { Major } \\
\text { challenge }\end{array}$} & \multicolumn{3}{|c|}{ Challenge Mild challenge } & \multicolumn{2}{|c|}{$\begin{array}{c}\text { Not a } \\
\text { challenge }\end{array}$} \\
\hline & & $\mathbf{N}$ & $\%$ & $\mathbf{N} \%$ & $\mathbf{N}$ & $\%$ & $\mathbf{N}$ & $\%$ \\
\hline 8 & Students have low-level English proficiency. & 32 & $64 \%$ & $1428 \%$ & 2 & $4 \%$ & 0 & $0 \%$ \\
\hline 9 & Students have a passive style of learning. & 11 & $22 \%$ & $3468 \%$ & 4 & $8 \%$ & 1 & $2 \%$ \\
\hline 10 & $\begin{array}{l}\text { Students are less confident and less prepared } \\
\text { for CLT. }\end{array}$ & 33 & $66 \%$ & $1224 \%$ & 5 & $10 \%$ & 0 & $0 \%$ \\
\hline 11 & $\begin{array}{l}\text { Students resist participating in communicative } \\
\text { class activities. }\end{array}$ & 33 & $66 \%$ & $1020 \%$ & 7 & $14 \%$ & 0 & $0 \%$ \\
\hline 12 & Students lack the motivation for developing & 5 & $10 \%$ & $2346 \%$ & 17 & $34 \%$ & 5 & $10 \%$ \\
\hline
\end{tabular}


The result of this section shows that more than half the teachers agreed on the major challenging nature of the first four situations, $64 \%(n=32)$ of teachers think that if students' level of English proficiency is low, it will be challenging for a teacher to apply CLT. 68\% $(n=34)$ of teachers believe that their students' passive style of learning is a challenge. All the teachers agreed upon the fact that the lack of confidence of students is a challenge whether it is major $66 \%$ or mild 10 , and no teacher considered it as not a challenge. Students' unacceptance of CLT forms a challenge for most of the teachers $66 \%(\mathrm{n}=33)$. Students' lack of motivation for developing communicative competence is seen by $10 \%(\mathrm{n}=5)$ of the teachers as a major challenge, on the contrary, the same number of teachers thought it is not a challenge. For Javid (2014), many problems are facing EFL teachers to truly activate activity-based syllabus in their classrooms, such as student's lack of interest and the sufficient English proficiency level In the present study context, though activity-based syllabus has been designed keeping in view the students' needs, the EFL teachers face several problems in executing it in its true sense. According to Javid (2014), these problems include students' low proficiency in the English language, lack of interest in learning English, EFL anxiety, over-crowded classes, and lack of technological support. It is observed that the majority of the students that have been categorized under a lower level of proficiency are having a problem with their self-esteem, in which they lack motivation (Shah \& Al-Bargi, 2013). Being a native speaker by most of the people in the country, the Arabic language has been used as the main medium of communication by Syrians for their daily life at the workplace, home, and education institutions, and hence, there is a small possibility of them to practice English as a conversational language during their daily use (Khan, 2011). From past studies, it has been found that many teachers were facing problems to build enthusiasm among their students to speak in English during the class session due to the reason that many of them were not good in English and very hesitant to communicate with their friends in this language outside of the classroom (Khan, 2011). Khan (2011) argued that even with good execution of sound planning, targeted curriculum, proper books, qualified educators, and constructive management, students were unable to achieve great communicative results. Besides, for the majority of Syrian universities, education is focused on teacher-centered instead of student-centered techniques, and a class is usually overcrowded with more than 50 students (Al-Mohanna, 2010). This could be one of the reasons that contribute to passiveness and the difficulty in achieving effective language learning among students. On top of that, a low level of proficiency among students presented low self-esteem and unprepared students. Hence, this possibly would be one of the main reasons for teachers to develop a good CLT method in their classrooms, and they tend to stick with the traditional teacher-centered way of teaching and learning.

Since the language function as a communicative tool to deliver feelings, expressions, meaning, and interaction among the speakers, students need to be given priority to practice the language they are acquiring in their learning experience. To meet these needs, the adoption of CLT could make the learners interact with each other, collective development of meaning, constructive and intentional engagement with language use, attentive to the response given by friends and instructors, achieving support, and attempting to integrate innovative ways towards improving performance, and taking chances and experimenting with the language.

\section{Policy-related Challenges}

In the third section of the questionnaire, teachers shared their thoughts on the different problems and obstacles posed in the current educational environment, as could be seen in the following Table 3 . Female EFL teachers cited a lack of AV supports in the curriculum (63\%), and the classes are generally too classes big for all students $(46 \%)$ as primary factors to unsuccessful of the CLT adoption in the learning process. The lack of AV supports was also cited as a problem by male EFL teachers (52\%). 
Another critical problem mentioned by EFL teachers (44\%) as an obstacle for them was a shortage of resources for communicative practices. Furthermore, $47 \%$ of teachers indicated that the current assessment system was unsatisfactory for the adoption of CLT as shown in Table 5.

Table 5. Difficulties and Challenges Related to The Educational System

\begin{tabular}{|c|c|c|c|c|c|c|c|c|c|}
\hline \multirow[t]{2}{*}{ No. } & \multirow[t]{2}{*}{ Statements } & \multicolumn{2}{|c|}{$\begin{array}{c}\text { Major } \\
\text { challenge }\end{array}$} & \multicolumn{2}{|c|}{ Challenge } & \multicolumn{2}{|c|}{ Mild challenge } & \multicolumn{2}{|c|}{$\begin{array}{c}\text { Not a } \\
\text { challenge }\end{array}$} \\
\hline & & $\mathbf{N}$ & $\%$ & $\mathbf{N}$ & $\%$ & $\mathbf{N}$ & $\%$ & $\mathbf{N}$ & $\%$ \\
\hline 13 & $\begin{array}{l}\text { There is a lack of enough } \\
\text { support from the } \\
\text { administration. }\end{array}$ & 5 & $10 \%$ & 14 & $28 \%$ & 26 & $52 \%$ & 5 & $10 \%$ \\
\hline 14 & $\begin{array}{l}\text { The traditional view on } \\
\text { teachers and students' } \\
\text { role is not compatible with } \\
\text { CLT. }\end{array}$ & 5 & $10 \%$ & 17 & $34 \%$ & 24 & $48 \%$ & 3 & $8 \%$ \\
\hline 15 & $\begin{array}{l}\text { Classes are too large for } \\
\text { the effective use of CLT. }\end{array}$ & & & & & & & & \\
\hline & & 4 & $8 \%$ & 2 & $24 \%$ & 19 & $38 \%$ & 15 & $30 \%$ \\
\hline 16 & $\begin{array}{l}\text { Lack of material for } \\
\text { communicative activities }\end{array}$ & 21 & $42 \%$ & 18 & $36 \%$ & 10 & $20 \%$ & 2 & $4 \%$ \\
\hline 17 & $\begin{array}{l}\text { CLT is unsuitable for } \\
\text { existing examination } \\
\text { system in Syria }\end{array}$ & 17 & $34 \%$ & 25 & $50 \%$ & 7 & $14 \%$ & 1 & $2 \%$ \\
\hline 18 & $\begin{array}{l}\text { The existing syllabus is not } \\
\text { suitable for } \\
\text { communicative activities. }\end{array}$ & 15 & $30 \%$ & 4 & $28 \%$ & 14 & $28 \%$ & 7 & $14 \%$ \\
\hline 19 & $\begin{array}{l}\text { Classrooms are not } \\
\text { equipped with } \mathrm{AV} \text { aids. }\end{array}$ & 35 & $70 \%$ & 11 & $22 \%$ & 4 & $8 \%$ & 0 & $0 \%$ \\
\hline
\end{tabular}

Nevertheless, in the present research findings, there is a small difference between males' reactions ( $46 \%$ as a moderate obstacle) and females' reactions ( $49 \%$ as not an obstacle) about the worthiness of the current curriculum for oral communication tasks. The explanation could be from the government's large funds to the education system, particularly in the teaching of the English language in schools and higher educational institutions. Professionals at the university level have revised and modified the current teaching method to match with the international policy requirements for second or foreign language education. Some prior research results are consistent with the current research findings. Similarly, Liton (2013) employed questionnaires to gather the required data from a number of 25 EFL teachers at several prestigious universities in Saudi Arabia. Due to the problem with large class size, the study findings showed that the EFL classroom is not favourable to task-based language classroom instruction. Alrabai (2011) carried out a study at KAU and reported that "overcrowded classrooms are seen as of of the major obstacle for teachers to incorporate CLT practices in their classrooms". Such restrictions arise as a result of the new policies imposed by the country's education policy and possibly would never get resolved unless the educational system's prime leaders take constructive forces.

\section{CLT-related Challenges}

Table 6 below shows indicate the results for the final part of the given questionnaire to 
respondents. They were required to give their opinions about the obstacles and problems they have encountered from the adoption of CLT.

Table 6. CLT-Related Difficulties and Challenges

\begin{tabular}{|c|c|c|c|c|c|c|c|c|c|}
\hline \multirow[t]{2}{*}{ No. } & \multirow[t]{2}{*}{ Statements } & \multicolumn{2}{|c|}{$\begin{array}{c}\text { Major } \\
\text { challenge }\end{array}$} & \multicolumn{2}{|c|}{ Challenge } & \multicolumn{2}{|c|}{$\begin{array}{c}\text { Mild } \\
\text { challenge }\end{array}$} & \multicolumn{2}{|c|}{$\begin{array}{c}\text { Not a } \\
\text { challenge }\end{array}$} \\
\hline & & $\mathrm{N}$ & $\%$ & $\mathrm{~N}$ & $\%$ & $\mathrm{~N}$ & $\%$ & $\mathrm{~N}$ & $\%$ \\
\hline 20 & $\begin{array}{l}\text { There is a lack of } \\
\text { effective and efficient } \\
\text { instruments to assess } \\
\text { communicative } \\
\text { competence. }\end{array}$ & 30 & $60 \%$ & 18 & 36 & 1 & $2 \%$ & 1 & $2 \%$ \\
\hline 21 & $\begin{array}{l}\text { CLT doesn't take into } \\
\text { account the } \\
\text { differences between } \\
\text { EFL and ESL } \\
\text { teaching contexts. }\end{array}$ & 9 & $18 \%$ & 24 & 48 & 15 & $30 \%$ & 2 & $4 \%$ \\
\hline 22 & $\begin{array}{l}\text { Western educational } \\
\text { assumptions are not } \\
\text { suitable within the } \\
\text { local context. }\end{array}$ & 5 & $10 \%$ & 17 & 34 & 19 & $38 \%$ & 9 & $18 \%$ \\
\hline 23 & $\begin{array}{lr}\text { CLT needs } & \text { specific } \\
\text { materials } & \text { for } \\
\text { teaching. } & \end{array}$ & 6 & $12 \%$ & 22 & 44 & 17 & $34 \%$ & 5 & $10 \%$ \\
\hline 24 & $\begin{array}{l}\text { CLT lacks } \\
\text { assessment } \\
\text { instruments in a local } \\
\text { context. }\end{array}$ & 5 & $10 \%$ & 24 & 48 & 17 & $34 \%$ & 4 & $8 \%$ \\
\hline
\end{tabular}

According to the current study's findings, $51 \%$ of female respondents and $37 \%$ of male respondents agree that enforcing CLT can be difficult due to the need for relevant teaching materials. As a result, it can be complicated to implement CLT, where the study materials accessible are not communicative enough for learners. Several CLT-based resources can be grabbed online or at bookstores, in which they are equipped with exercises. There are also books for teachers that they can adopt in their classroom teaching. a

In terms of the incompetency of existing western educational standards in the local setting, male EFL teachers $(45 \%)$ categorised it as an obstacle, while females $(45 \%)$ categorised it as a minor obstacle. We may propose that the concept of CLT was constructed and established in Europe, and the practice in Efl settings can pose a challenge among language educators. Nevertheless, there is a continuing need to consider the gap between theoretical and practices, necessitating further optimism on the part of EFL teachers regarding the viability of CLT.

It has also been identified there is an absence of reliable and accessible testing tools (male 48\%; female $43 \%$ ) to measure students' communication skills in a specific local setting (male $44 \%$; female 49\%) as an obstacle. In pursuit of the appropriate undertaking, Alptekin (2002) proposes that learners can be more actively involved in the discussion if the language is standardized based on the local use to establish an actual communicative behaviour that could recognize English as a foreign language. 
Based on the existing research background conditions, the results of the current study emphasize many guidelines for successful CLT implementation in Syrian EFL classroom settings. To begin, the first step that could be done by EFL teachers is that they must receive continuous CLT preparation training that focuses on constructive hands-on lessons to improve EFL teachers' abilities in broad facets of CLT. In addition, there must be widespread availability of information and instructional assistance in the curriculum. Even it is policy-related, one other significant thing for CLT to figure out is reducing the number of students in one single class, which can make the learning experience for students simpler.

To ensure the implementation's success, the highest effort must be initiated, starting with policy executions by the policymakers. This effort could entail the following process: First, the EFL program should be reorganized to make more time available for additional task-based practices that empower students to engage students in experiencing a more effective learning experience. Second, EFL teachers must invest in continuing career growth to strengthen their expertise and remain updated with market dynamics. Overcrowding in classrooms was thought to be one of the most significant barriers to CLT adoption in an EFL education environment. Second, a critical institutional reorganization of the number of students in classrooms must be firmly taken into consideration. Similarly, the fourth focus should be put on rendering the classroom setting more enticing and conducive for the introduction of learner-based practices. This involves including adequate technology-enhanced resources in schools, such as data displays, web and computer connections, and interactive boards for versatile group projects.

\section{Conclusion and Implications}

The current study examined the problems and obstacles that EFL teachers face while introducing CLT in their teaching process. Obstacles in adopting CLT were identified as related to teachers, students, the education system, as well as the construction of the CLT in Syria. Intriguingly, after considering all of the mentioned obstacles, the majority of EFL teachers were supportive of implementing CLT in their lessons. Several prejudices were discovered to be widespread among EFL students, who were believed to have evolved as a result of conventional teaching techniques. These biases, such as "no teaching of grammar" and "only allowed to talk," were discovered to be the result of a poor understanding and adherence to the CLT method. Respondents stated that they are not getting access to CLT resources and not being able to schedule CLT exercises for their students due to restrictions such as extensive curriculums, insufficient time, and a scarcity of CLT preparation as EFL instructors. Passive learning style, loss of confidence and preparation, lack of enthusiasm, low-level competence, and refusal to engage in communicative tasks were identified as significant student-related obstacles to integrating CLT. These problems may have arisen from the students' inability to use English outside of the classroom, which has been identified to not always be something practicable. A country's educational process is important in guiding students' requirements and success in a particular field. In the current study background, the Syrian government has taken critical steps to establish English as a foreign language, including large funds, qualified educators, and reinforced learning and teaching materials. Even then, problems such as an extensive amount of students in classrooms, a shortage of study materials for communicative practices, a scarcity of technologyenhanced supports in the curriculum, and the new assessment system presented substantial obstacles to incorporating CLT in its real essence. Giving proper training to students and teachers on the way to navigate around ICT tools in teaching and studying English can be a great assist in the construction of a robust foundation that would increase the quality of education in Syrian educational institutions. It means the institutions remain down the road that has contributed to the 21 st-century education system that is accessible in developing countries. 
Based on the findings of the present study, some recommendations would improve the use of CLT in the English classroom in public schools of Syria. The following recommendations are made based on the problems that were identified in this paper: English language teachers should be trained in CLT. They need to be made aware of the CLT principles and how these principles are practiced within language classrooms. The curriculum needs to be edited to focus on the elements of CLT. The schools should be provided with adequate infrastructure and necessary technological gadgets that are necessary for CLT implementation. The size of the class is exceptionally large so students should be divided into multiple classes. In the Syrian context, teachers needed to be aware of the importance of CLT in teaching as some of them still believe that the Grammar Translation Method (GTM) is better than CLT. The present testing system also needs to be modified by including all four skills in the testing system.

\section{References}

Ahmed, M. (2016). Communicative Language Teaching: A Practical Scenario in the Context of Bangladesh. Advances in Language and Literary Studies, 7(5), 97-104.

Alakrash, H., Razak, N, A. (2019). Motivation towards the application of ICT in English language learning among Arab EFL students. Journal of Advanced Research in Dynamical \& Control Systems, 11, 1197-1203.

Alakrash, HM, Razak, NA, \& Bustan, ES (2020). The Effectiveness of Employing Telegram Application in Teaching Vocabulary: A Quasi Experimental Study. Multicultural Education, 6(1).

Alakrash, H., Razak, N. A., \& Krish, P. (2021). Social Network Sites in Learning English; An Investigation on Attitudes, Digital Literacy and Usage. LINGUISTICA ANTVERPIENSIA, 26-43.

Alakrash, H. M., \& Razak, N. A. (2020a). Redesigning the English Classroom Towards Fourth Industrial Revolution, Are the Students Motivated?. The Asian ESP Journal, 16(4).

Alakrash, H. M., \& Razak, N. A. (2020b). Towards the Education 4.0, Readiness Level of EFL Students in Utilising Technology-Enhanced Classroom. International Journal of Innovation, Creativity and Change, 13(10).

Al Asmari, A. A. (2015). Communicative language teaching in EFL university context: Challenges for teachers. Journal of Language Teaching and Research, 6(5), 976-984.

Alamri, W. A. (2018). Communicative Language Teaching: Possible Alternative Approaches to CLT and Teaching Contexts. English Language Teaching, 11(10), 132-138.

Alkamel, M., \& Chouthaiwale, S. S. (2020). ICT Availability and Uses among Yemeni University EFL Students. TESOL and Technology Studies, 1(1), 1-9.

Al-Mohanna, A. (2010). English Language Teaching in Saudi Arabian Context: How Communicatively Oriented is it? Journal of King Saud University - Languages and Translation, $22,69-88$.

Alptekin, C. (2002). Towards intercultural communicative competence in ELT. ELT Journal, 56(1), 57-64.

Alrabai, F.A. (2011). Motivational instruction in practice: Do EFL instructors at King Khalid University motivate their students to learn English as a foreign language? Arab World English Journal, 2(4), 257-285.

Ansarey, D. (2012). Communicative Language Teaching in EFL Contexts: Teachers Attitude and Perception in Bangladesh. ASA University Review, 6(1). 
Butler, Y. G. (2011). The implementation of communicative and task-based language teaching in the Asia-Pacific region. Annual Review of Applied Linguistics, 31, 36.

Chang, M. (2011). EFL teachers' attitudes toward communicative language teaching in Taiwanese college. Asian EFL Journal, 53(1), 17-34.

Coskun, A. (2011). Investigation of the Application of Communicative Language Teaching in the English Language Classroom--A Case Study on Teachers' Attitudes in Turkey. Online Submission, 2(1).

Dornyei, Z. (2013). Communicative language teaching in the twenty-first century: The principled communicative approach. J. Arnold, \& T. Murphy, Meaningful Action (Eds.), 161-171.

Fadilah, E. (2018). Rethinking the maintenance of CLT in Indonesia: A response to Ariatna's "The need for maintaining CLT in Indonesia." Tesol Journal, 9(1), 224-236.

Farooq, M. U. (2015). Creating a Communicative Language Teaching Environment for Improving Students' Communicative Competence at EFL/EAP University Level. International Education Studies, 8(4), 179-191.

Jafari, S. M., Shokrpour, N., \& Guetterman, T. (2015). A mixed methods study of teachers' perceptions of communicative language teaching in Iranian high schools. Theory and Practice in Language Studies, 5(4), 707-718.

Javid, C.Z. (2014). Measuring language anxiety in an EFL context. Journal of Education and Practice. 5(25), 180- 193.

Khan, I.A. (2011). Challenges of teaching/learning English and management. Global Journal of Human Social Sciences, 11(8), 68-80.

Khoja, B., \& Mohapatra, D. (2017). The real story of English language teaching in Syrian high schools and the bumpy transition into the university level. Online Proceedings of the International Conference: DRAL, 3 .

Liton, H.A. (2013). EFL Teachers' perceptions, evaluations and expectations about English language courses as EFL in Saudi Universities. International Journal of Instruction, 6(2), 19-34.

Mowlaie, B., \& Rahimi, A. (2010). The effect of teachers' attitude about communicative language teaching on their practice: Do they practice what they preach? Procedia-Social and Behavioral Sciences, 9, 1524-1528.

Mustapha, S. M., \& Yahaya, R. A. (2013). Communicative Language Teaching (CLT) in Malaysian context: its' implementation in selected community colleges. Procedia-Social and Behavioral Sciences, 90, 788-794.

Nayeen, C. M. J., Islam, K. M. A., Chowdhury, F. N., \& Zayed, N. M. (2020). Testing Communicative Language Teaching (CLT) through English for Today (EFT) in Bangladesh: Challenges Faced by Tertiary Students Initially. American International Journal of Education and Linguistics Research, 3(2), 19-27.

NGOC, K. M. A. I., \& Iwashita, N. (2012). A comparison of learners' and teachers' attitudes toward communicative language teaching at two universities in Vietnam. University of Sydney Papers in TESOL, 7.

Ozsevik, Z. (2010). The use of communicative language teaching (CLT): Turkish EFL teachers' perceived difficulties in implementing CLT in Turkey.

Prastyo, H. (2015). The implementation of grammar translation method (GTM) and communicative language teaching (CLT) in teaching integrated english. Indonesian EFL Journal: Journal of 
ELT, Linguistics, and Literature, 1(2), 170-182.

Rahman, M. M., Pandian, A., \& Kaur, M. (2018). Factors affecting teachers' implementation of communicative language teaching curriculum in secondary schools in Bangladesh. The Qualitative Report, 23(5), 1104-1126.

Razak, N. A., Alakrash, H. M., \& Sahboun, Y. (2018). English Language Teachers' readiness For the Application of Technology Towards Fourth Industrial Revolution Demands. Asia-Pacific Journal of Information Technology and Multimedia, 7(2-2), 89-98.

Razak, N. A., Yassin, A. A., \& Maasum, T. N. R. T. M. (2020). Formalizing Informal CALL in Learning English Language Skills. In Enhancements and Limitations to ICT-Based Informal Language Learning: Emerging Research and Opportunities (pp. 161-182). IGI Global.

Roy, S. (2016). Challenges to Implementing Communicative Language Teaching (CLT) in Bangladesh. Language in India, 16(3).

Shah, S.R. and Al-Bargi. A. (2014). The use of lingua franca core: A classroom based study on Saudi EFL learners' pronunciation. Language, Individual \& Society, 8, 476-498.

Sreehari, P. (2012). Communicative Language Teaching: Possibilities and Problems. English Language Teaching, 5(12), 87-93.

Van Nguyen, L. (2010). Computer mediated collaborative learning within a communicative language teaching approach: A sociocultural perspective. The Asian EFL Journal Quarterly March 2010, 12(202).

Wei, L., Lin, H.-H., \& Litton, F. (2018). Communicative language teaching (CLT) in EFL context in asia. Asian Culture and History, 10(2), 1-9.

Whong, M. (2013). A linguistic perspective on communicative language teaching. The Language Learning Journal, 41(1), 115-128.

Zare-Behtash, E., Banaruee, H. (2017). Critical Evaluation of the New Headway Advanced and the ILI Advanced Series: A comparison of curricular components and CLT objectives based on ACTFL. International Journal of Applied Linguistics and English Literature, 6(5), 182-190. 